\title{
Farmers' Willingness to Continue Landscape Integrated Pest Management Programs in Central Java and East Java Indonesia
}

\author{
Hani Perwitasari \\ Department of Agricultural Socio-Economics \\ Universitas Gadjah Mada \\ Yogyakarta, Indonesia \\ hani.perwita@ugm.ac.id \\ Suhatmini Hardyatuti \\ Department of Agricultural Socio-Economics \\ Universitas Gadjah Mada \\ Yogyakarta, Indonesia \\ suhatmini_h@ugm.ac.id
}

\author{
Irham \\ Department of Agricultural Socio-Economics \\ Universitas Gadjah Mada \\ Yogyakarta, Indonesia \\ irham@ugm.ac.id \\ Slamet Hartono \\ Department of Agricultural Socio-Economics \\ Universitas Gadjah Mada \\ Yogyakarta, Indonesia \\ hartono.slamet@yahoo.com
}

\begin{abstract}
Integrated Pest Management (LIPM) is an innovation of Integrated Pest Management program to achieve effective sustainable agriculture in a wide area. This program has been implemented in some regions as the Indonesia's food storages including Central Java, East Java and West Java. Research on the application of LIPM is generally related to economic aspects. This study examines farmers' willingness to continue LIPM and the factors that influence it. The research was conducted by surveying 109 farmers in Banyumas and Bojonegoro regencies who are still performing the program and the analysis was done by multinomial logit model. Based on the results of the research, it is revealed that the level of the willingness was $44.65 \%$, meaning that farmers are still hesitant to continue the LIPM. Age, LIPM farmers and friendship predicted the willingness to continue LIPM. In other words, it is indicated that farmers will become more willing to continue LIPM Program if they believe that the program has a positive outcome. Nevertheless, the constraints in implementing the LIPM program, attitudes towards property rights, the contribution of farming income and farming experience make farmers less willing to continue the program due to the fact that the more experienced the farmers, especially those who rented out the land and had high farming income, the more impossible for them to avoid applying pesticides for fear that their rice farming will be at risk.
\end{abstract}

Keywords-Central Java, East Java, LIPM, Willingness to Continue

\section{INTRODUCTION}

Landscape Integrated Pest Management (LIPM) is an IPM program innovation. According to the Food and Agriculture Organization the LIPM program is a program to encourage sustainable "healthy" rice production and ensure more effective pest management with application towards communal pest management in an area [1]. In addition, [2] stated that two approaches have been added in the concept of LIPM from the previous IPM, namely the scale of the ecosystem based management overlay (covering an area of 25 ha) and the owner of the land as a group. Managing IPM on a large scale with continuous group observation is expected to reduce the population and source of inoculum so that the number of populations and inoculums that infect each plot of rice fields will be reduced. Reducing the number of pest populations will reduce farmers' concerns so that it will reduce the use of pesticides. When the population of the General Balance Line is low, other environmentally-friendly management technologies can be used to safeguard the General Balance Line so that it remains below the economic threshold.

The application of the LIPM program is carried out with refugia flower planting. According to [3] refugia flower planting is a way to manipulate the ecosystem. This is supported by [4] stating that planting flowers can improve biodiversity and provide effective shelter and alternative food sources for predators and parasitoids as natural enemies of rice pests.

[5], it is known that from six districts that are still continuing to implement Landscape IPM programs, it is only Banyumas Regency and Bojonegoro Regency that are still implementing the Landscape IPM program. However, according to [6], the majority of Landscape IPM farmers are highly encouraged and enthusiastic in adopting the Landscape IPM program.

In the agricultural ecosystem, IPM is to work together in the program collectively in the regulation of land purposely to achieve the effectiveness of the program increases. [7] also identified pest control as a very suitable method for collective management in agricultural ecosystems. [8] claimed that if technical solutions are inadequate, farmers must work together to succeed the IPM program [8]. Research by [9] showed the willingness of farmers to cooperate in pest controlling for believing that they can reap benefits from cooperation, have a farm similar to neighboring farms, become the active members of a community organization, trust in agricultural extension agents for pest control information and pay attention to the effects of pesticides towards the environment. Farmers who have these characteristics will be more willing to implement IPM than farmers who do not. 
This study aims to determine the willingness to continue LIPM technology and the factors that influence it. This is important because it provides insights related to things that can foster collaboration between farmers in the application of Landscape IPM programs

\section{METHODS}

The location of the study was determined using a purposive method, by way of deliberate selection to adjust to the research objectives [10]. The determination of the location was based on the management of LIPM collaboration between the Indonesian government and FAO in Pliken Village, Kembaran District, Banyumas Regency, Central Java Province and Bendo Village, Kapas District, Bojonegoro Regency, East Java Province as seen in Figure 1.

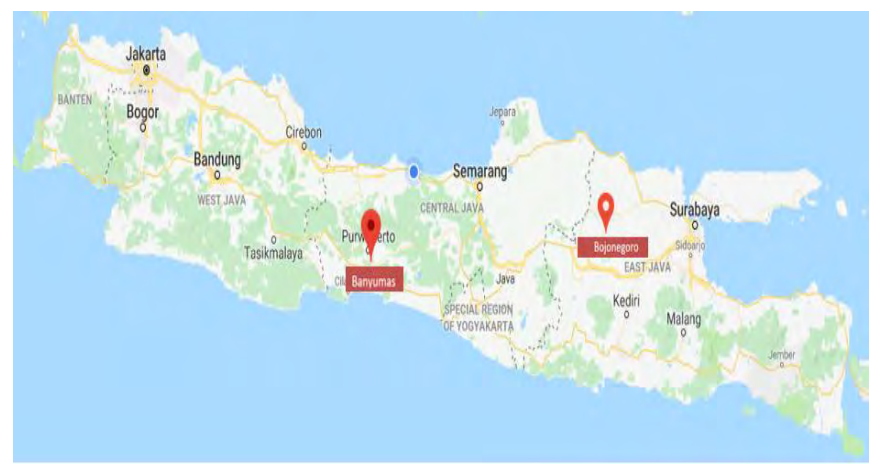

Figure 1. Java Island Map (Source: Google Map (2018)

The determination of the farmer group was determined by cluster sampling. [11] stated that cluster sampling is a sampling technique with group principles that are not directly taken to the observation unit, but carried out through sampling from observation unit groups. Farmers who were taken as the sample were the farmers in the Sumber Rejeki farmer group in Pliken Village, Banyumas Regency and Mekar Jaya Farmer Group in Bendo Village, Bojonegoro District. These sampled farmers were divided into several categories, (1) farmers joining the FAO program but previously not implementing the IPM programs; (2) farmers joining the FAO program and previously implementing IPM programs; (3) farmers not participating in the FAO and PHT programs but now implementing PHTL; and (4) farmers not joining the FAO program but previously implementing the IPM program and now implementing PHTL. Farmers were chosen randomly at 109 .

Farmers' willingness to continue and implement LIPM programs was measured through 5 attitudinal dimensions: willingness, constraints on the application of LIPM programs, expected outcomes, attitudes about the environment and attitudes about property rights. The validity and reliability of all variables in the study were tested and then the responses to the answers from the statement items in the form of ordinal data were transformed into interval data by means of the Summed Rating Method. Construction indicators of willingness to implement and continue the LIPM Program can be seen in Table 3.1.
Table 1. Indicators of Willingness to Continue LIPM Programs

\begin{tabular}{|c|c|c|}
\hline $\begin{array}{c}\text { Social Cohesion } \\
\text { Dimension }\end{array}$ & Item & Scale \\
\hline $\begin{array}{l}\text { Neighborhood } \\
\text { interaction }\end{array}$ & Collaboration in farming & $1-5$ \\
\hline $\begin{array}{l}\text { Neighborhood } \\
\text { friendships }\end{array}$ & $\begin{array}{l}\text { Support and assistance } \\
\text { from friends in farming }\end{array}$ & $1-5$ \\
\hline $\begin{array}{l}\text { Attitudinal } \\
\text { Dimension }\end{array}$ & & \\
\hline $\begin{array}{c}\text { Willingness to } \\
\text { continue LIPM } \\
\text { program }\end{array}$ & $\begin{array}{l}\text { The ability to continue } \\
\text { LIPM work steps }\end{array}$ & $1-5$ \\
\hline Constraints & $\begin{array}{l}\text { Barriers or difficulties } \\
\text { faced by farmers in } \\
\text { implementing } \\
\text { programs }\end{array}$ & $1-5$ \\
\hline $\begin{array}{l}\text { Outcome } \\
\text { expectations }\end{array}$ & $\begin{array}{l}\text { Farmers' expectations of } \\
\text { the benefits that can be } \\
\text { obtained in implementing } \\
\text { LIPM }\end{array}$ & $1-5$ \\
\hline $\begin{array}{l}\text { Environmental } \\
\text { attitudes }\end{array}$ & $\begin{array}{l}\text { Farmers' response to the } \\
\text { importance of protecting } \\
\text { natural resources and the } \\
\text { environment }\end{array}$ & $1-5$ \\
\hline $\begin{array}{l}\text { Private property } \\
\text { rights attitudes }\end{array}$ & $\begin{array}{l}\text { Farmers' responses or } \\
\text { responses to land and } \\
\text { home use to support the } \\
\text { LIPM program }\end{array}$ & $1-5$ \\
\hline
\end{tabular}

The model used to determine the factors that influenced the willingness to continue and implement PHT programs were analyzed using multinomial logit. Multinomial logit model used in the following research is presented below:

$\log \left(\frac{\operatorname{Pr}\left(Y_{i}=m\right)}{\operatorname{Pr}\left(Y_{i}=1\right)}\right)=\alpha_{\mathrm{m}}+\beta_{\mathrm{m} 1} \mathrm{X}_{\mathrm{i} 1}+\beta_{\mathrm{m} 2} \mathrm{X}_{\mathrm{i} 2}+\beta_{\mathrm{m} 3} \mathrm{X}_{\mathrm{i} 3}+\beta_{\mathrm{m} 4} \mathrm{X}_{\mathrm{i} 4}+$ $\beta_{\mathrm{m} 5} \mathrm{X}_{\mathrm{i} 5}+\beta_{\mathrm{m} 6} \mathrm{X}_{\mathrm{i} 6}+\beta_{\mathrm{m} 7} \mathrm{X}_{\mathrm{i} 7}+\beta_{\mathrm{m} 8} \mathrm{X}_{\mathrm{i} 8}+\beta_{\mathrm{m} 9} \mathrm{X}_{\mathrm{i} 9}+\beta_{\mathrm{m} 10} \mathrm{X}_{\mathrm{i} 10}+$ $\beta_{\mathrm{m} 11} \mathrm{X}_{\mathrm{i} 11}+\mathrm{D}_{1}+\mathrm{D}_{2}+\mathrm{D}_{3}=\mathrm{Zmi}$

where:

$\mathrm{Z}_{\mathrm{mi}} \quad=$ Willingness to Continue LIPM Program $(\mathrm{m}=2,3,4,5)$

$\mathrm{X}_{1} \quad=$ Neighborhood interaction

$\mathrm{X}_{2} \quad=$ Neighborhood friendships

$\mathrm{X}_{3}=$ Constraints to implement LIPM Program

$\mathrm{X}_{4} \quad=$ Outcome expectations

$\mathrm{X}_{5} \quad=$ Environmental attitudes

$\mathrm{X}_{6} \quad=$ Private property rights attitudes

$\mathrm{X}_{7} \quad=$ On farm Revenue Contribution (Rupiah)

$\mathrm{X}_{8} \quad=$ Age (year)

$\mathrm{X}_{9} \quad=$ Farming experience (year)

$\mathrm{X}_{10}=$ Land Area $(\mathrm{Ha})$

$\mathrm{X}_{11}=$ Education (Year)

$\mathrm{D}_{1} \quad=$ LIPM Farmers $\left(\mathrm{D}_{1}=1\right.$, category $1 ; \mathrm{D}_{1}=0$, otherwise)

$\mathrm{D}_{2}=$ LIPM Farmers $\left(\mathrm{D}_{1}=1\right.$, category $2 ; \mathrm{D}_{1}=0$, otherwise) 


$\begin{aligned} \mathrm{D}_{3}= & \text { LIPM Farmers }\left(\mathrm{D}_{1}=1, \text { category } 3 ; \mathrm{D}_{1}=0,\right. \\ & \text { otherwise }) \\ \alpha_{\mathrm{m}} & \text { Intercept } \\ \beta_{\mathrm{mk}}= & \text { Regression coefficient }\end{aligned}$

\section{RESULTS AND DISCUSSION}

\section{A. Willingness to Continue LIPM Program}

Willingness to Continue (WTC) LIPM Program is the hope or will of farmers to implement the program. This willingness becomes an important thing to know because it can be used to evaluate programs that have been implemented. This willingness was measured by several statement items as the steps of the LIPM program including [12] : (1) Technical planning for planting with groups; (2) Observation of the development of rice plants; (3) Observation of the development of refugia plants; (4) Observing the number of Plant Disturbing Organisms; (5) Observation of the number of natural enemies; (6) Measurement of water level, (7) measurement of soil pH; (8) water $\mathrm{pH}$ measurement; (9) Reports of joint observations of the group; (10) Evaluation of observation reports; (11) Application of LIPM with the members of farmer groups; (12) Planting of refugia flowers that can reduce the number of pests of rice plants; (13) Planting refugia flowers with mutual cooperation; (14) Planting refugia flowers for the beauty of the environment; and (15) Planting refugia flowers for free seeds. However, of 15 items of statement, items 6,7 and 8 were deleted for being invalid. The measurement of water level, soil and water $\mathrm{pH}$ was found difficult for farmers to do as they did not have the adequate tools to do this.

Figure 1 shows that overall the WTC LIMP program was 44.65 percent. The level of willingness was not too high because even though the farmers in Banyumas even though had implemented the planted land program, it was still up to the planthopper pests, so they still planted refugia flowers for the land beauty. On the other hand, farmers in Bojonegoro Regency still believed that refugia flower planting could reduce pests. One of the studies related to the implementation of IPM was conducted by Putri's research [6]. This study concerned with the level of adoption of LIPM by rice farmers in Pliken Village, Kembaran Subdistrict, Banyumas Regency which was also included in the medium category.

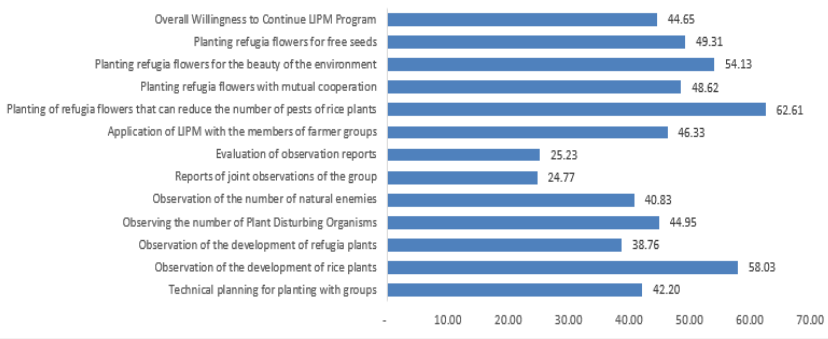

Figure 2. Willingness to Continue LIPM Program

Planting refugia flowers to reduce pest attacks, observing the development of rice plants and the beauty of refugia flowers became the main reasons for farmers to continue the PHTL program which could be recognized from the willingness level at $62.61,58.03$ and 54.13 percent. However, farmers were still reluctant to make observations on refugia flowers as they needed to devote much time to trim the flowers and clean the land so that it was not lush. In addition, farmers felt objected to evaluate and make some observational reports because only 20.18 percent of farmers had received high school and university education.

\section{B. Factors Affecting Willingness to Continue LIPM Program}

Willingness to continue (WTC) LIPM program can be increased through the factors that influence it. This study used a multinomial logit model to determine the WTC factor. As shown in Table 3 it can be seen that the value of -2 Log Likelihood (-2LL) would decrease to 139,016 when the variable was entered in the model. A decrease in value of $2 \mathrm{LL}$ was significant at a 1 percent error rate. In addition, based on cox and snell values of 0.679 and Nagelkerke values of 0.746 , meaning 74.60 percent of the dependent variable can be explained by independent variables, while the remaining 25.4 percent was explained by other independent variables not included in the model.

Model 1: Constraints in the management of Landscape IPM programs, attitudes toward private property rights, farm income contribution and LIPM farmers had a significant influence on the model. This has been indicated by a significance value lower than 0.05 . The reference variable of this research model was the willingness to continue the LIPM program so that: (1) the problem of LIPM management affected the probability of the willingness of farmers to continue the LIPM program to be lower than their unwillingness with the coefficient of -0.117 and an odds ratio of 0.889 ; (2) attitudes towards private property affected the probability of the willingness of farmers to continue the LIPM program to be lower than their unwillingness with a coefficient of -0.178 and an odd ratio of 0.837 ; (3) the contribution of farm income influenced the probability of the willingness of farmers to continue the LIPM program to be lower than their unwillingness with the coefficient of -0.082 and with an odds ratio of 0.921 ; and (4) LIPM category 1 farmers affected the probability of farmers willingness to continue the LIPM program higher than their unwillingness with a coefficient of 7,570 and an odds ratio of 1,938 .

Model 2: Attitudes toward private property rights, age, farming experience and LIPM farmers had a significant influence on the model. This was indicated by the significance value of attitudes toward private property rights and LIPM farmers below 0.05, while the age and experience of farming had a significance value below 0.05 . From model 2 , it can be seen that: (1) attitudes toward private property affected the probability of farmers' willingness to continue the LIPM program lower than the lack of willingness with a coefficient of -0.141 and an odds ratio of 0.869 ; (2) age affected the probability of the willingness of farmers to continue the LIPM program higher than the lack of willingness with a coefficient of 0.374 and an odds ratio of 1.454 ; (3) farming experience influenced the probability of farmers' willingness to continue the LIPM program lower than their unwillingness with the coefficient of -0.226 and an odds ratio of 0.798 ; (4) LIPM category 1 farmers affected the probability of the willingness of farmers to continue the LIPM program higher than the lack of willingness with a coefficient of 3.408 and a value of 30.192 odds ratio. 
Table 2. Factors Affecting Willingness to Continue (WTC) PHTL Program

\begin{tabular}{|c|c|c|c|c|c|}
\hline Chi-square & Df & Sig & \multicolumn{2}{|c|}{$\begin{array}{c}\text { Cox \& Snell } \\
\mathbf{R}^{2} \\
\end{array}$} & Nagelkerke $\mathbf{R}^{2}$ \\
\hline 123.982 & 42 & .000 & 139.016 & .679 & .746 \\
\hline Model & $Z^{a}$ & $B$ & Std. Error & Sig. & $\operatorname{Exp}(B) /$ Odd Ratio \\
\hline \multirow[t]{18}{*}{1} & Intercept & 33.559 & 21.657 & .121 & \\
\hline & $\mathrm{X} 1$ & -.039 & .061 & .521 & .962 \\
\hline & $\mathrm{X} 2$ & -.057 & .061 & .348 & .945 \\
\hline & $\mathrm{X} 3$ & -.117 & .058 & $.043 * *$ & .889 \\
\hline & $\mathrm{X} 4$ & -.114 & .103 & .269 & .893 \\
\hline & $\mathrm{X} 5$ & -.091 & .096 & .345 & .913 \\
\hline & X6 & -.178 & .083 & $.031 * *$ & .837 \\
\hline & $\mathrm{X} 7$ & -.082 & .039 & $.034 * *$ & .921 \\
\hline & $\mathrm{X} 8$ & .205 & .202 & .312 & 1.227 \\
\hline & X9 & .041 & .189 & .830 & 1.041 \\
\hline & $\mathrm{X} 10$ & .000 & .000 & .634 & 1.000 \\
\hline & $\mathrm{X} 11$ & -.407 & .365 & .264 & .665 \\
\hline & {$[\mathrm{D} 1=.00]$} & 7.570 & 3.553 & $.033 * *$ & $1.938 \mathrm{E} 3$ \\
\hline & {$[\mathrm{D} 1=1.00]$} & $0^{\mathrm{b}}$ & . & . & . \\
\hline & {$[\mathrm{D} 2=.00]$} & -5.002 & 4.506 & .267 & .007 \\
\hline & {$[\mathrm{D} 2=1.00]$} & $0^{\mathrm{b}}$ & . & . & . \\
\hline & {$[\mathrm{D} 3=.00]$} & -5.431 & 3.619 & .133 & .004 \\
\hline & {$[\mathrm{D} 3=1.00]$} & $0^{\mathrm{b}}$ & . & & \\
\hline \multirow[t]{18}{*}{2} & Intercept & 2.920 & 7.872 & .711 & \\
\hline & $\mathrm{X} 1$ & -.041 & .038 & .286 & .960 \\
\hline & $\mathrm{X} 2$ & .029 & .032 & .354 & 1.030 \\
\hline & $\mathrm{X} 3$ & -.046 & .037 & .221 & .955 \\
\hline & $\mathrm{X} 4$ & -.076 & .051 & .135 & .927 \\
\hline & $\mathrm{X} 5$ & .000 & .048 & .998 & 1.000 \\
\hline & X6 & -.141 & .056 & $.012 * *$ & .869 \\
\hline & $\mathrm{X} 7$ & -.018 & .017 & .274 & .982 \\
\hline & $\mathrm{X} 8$ & .374 & .117 & $.001 * * *$ & 1.454 \\
\hline & X9 & -.226 & .080 & $.005^{* * *}$ & .798 \\
\hline & $\mathrm{X} 10$ & .000 & .000 & .709 & 1.000 \\
\hline & $\mathrm{X} 11$ & .115 & .209 & .581 & 1.122 \\
\hline & {$[\mathrm{D} 1=.00]$} & 3.408 & 1.631 & $.037 * *$ & 30.192 \\
\hline & {$[\mathrm{D} 1=1.00]$} & $0^{\mathrm{b}}$ & . & - & . \\
\hline & {$[\mathrm{D} 2=.00]$} & 2.916 & 1.831 & .111 & 18.472 \\
\hline & {$[\mathrm{D} 2=1.00]$} & $0^{\mathrm{b}}$ & . & . & . \\
\hline & {$[\mathrm{D} 3=.00]$} & -.050 & 2.047 & .981 & .951 \\
\hline & {$[\mathrm{D} 3=1.00]$} & $0^{\mathrm{b}}$ & . & . & . \\
\hline \multirow[t]{18}{*}{3} & Intercept & 2.180 & 6.599 & .741 & \\
\hline & $\mathrm{X} 1$ & -.022 & .030 & .462 & .978 \\
\hline & $\mathrm{X} 2$ & .062 & .025 & $.011 * *$ & 1.064 \\
\hline & $\mathrm{X} 3$ & .037 & .030 & .220 & 1.037 \\
\hline & $\mathrm{X} 4$ & -.031 & .042 & .454 & .969 \\
\hline & $\mathrm{X} 5$ & -.034 & .042 & .421 & .967 \\
\hline & X6 & -.103 & .047 & $.029 * *$ & .902 \\
\hline & X7 & -.010 & .015 & .519 & .991 \\
\hline & X8 & .278 & .104 & $.008^{* * *}$ & 1.320 \\
\hline & X9 & -.149 & .067 & $.027 * *$ & .862 \\
\hline & $\mathrm{X} 10$ & .000 & .000 & .556 & 1.000 \\
\hline & $\mathrm{X} 11$ & -.002 & .176 & .993 & .998 \\
\hline & {$[\mathrm{D} 1=.00]$} & .167 & 1.466 & .909 & 1.181 \\
\hline & {$[\mathrm{D} 1=1.00]$} & $0^{\mathrm{b}}$ & . & . & . \\
\hline & {$[\mathrm{D} 2=.00]$} & -.169 & 1.465 & .908 & .845 \\
\hline & {$[\mathrm{D} 2=1.00]$} & $0^{\mathrm{b}}$ & . & . & . \\
\hline & {$[\mathrm{D} 3=.00]$} & -.873 & 1.833 & .634 & .418 \\
\hline & {$[\mathrm{D} 3=1.00]$} & $0^{\mathrm{b}}$ & . & . & \\
\hline
\end{tabular}

Note: $* *$ Significant at 5\%.*** Significant at $1 \%$.
Model 3: Friendship with neighbors, attitudes towards private property, age and farming experience had a significant influence on the model. This was indicated by the significance value of friendship with neighbors, attitudes toward personal property rights and farming experience below 0.05 , while age had a significance value below 0.05 . The results of model 3 showed that: (1) friendship with neighbors influenced the probability of the willingness of farmers to continue the LIPM program higher than their doubts with a coefficient of 0.062 and an odds ratio of 1.064; (2) attitudes towards private property affected the probability of the willingness of farmers to continue the LIPM program lower than their doubts with a coefficient of -0.103 and an odds ratio of 0.902 ; (3) age affected the probability of farmers willingness to continue the LIPM program lower than their doubts with a coefficient of 0.278 and an odds ratio of 1.320; and (4) farming experience affected the probability of farmers' willingness to continue the LIPM program higher than their doubts with a coefficient of -0.149 and an odds ratio of 0.862 .

Constraints in the management of Landscape IPM programs, attitudes to property rights, income contributions and business experience negatively affected the willingness to continue the LIPM program. This was due to the constraints of farmers who needed to spend more time and energy to maintain interest on refugia, coordination with other members of the farmer group, and the previous experience telling that it was much easier for them to not implement the LIPM program. In addition, 61.47 percent of farmers' land ownership was their own, so farmers felt that if they did not use pesticides, their rice farming would be more at risk. Likewise, the contribution of farm income was an average of 65.22 percent and in Banyumas District there was a massive attack of plant hopper, which negatively affected the willingness to continue the LIPM program. This was different from 2016 when rice farming income that applied LIPM was higher than the one without any LIPM implementation [12].

Landscape Integrated Pest Management (LIPM) farmers who previously participated in the LIPM program and previously implemented IPM programs have used to implement measures in the program so that the willingness to continue the program was higher than other farmers. Besides, age also had a positive effect on willingness because it could change the mindset to be wiser towards the importance of implementing sustainable agriculture. In addition, with the elder age, the farmers would also have more networks of friends so as to facilitate the implementation of LIPM programs carried out in groups.

This is in line with previous studies. According to [13] socioeconomic factors namely farmers' income, farmers' knowledge about IPM, farmers' attitudes towards IPM and farmers' participation in IPM field school influence the implementation of IPM. [14] also stated that field schools can also increase IPM adoption. Research on the willingness to implement agricultural conservation programs carried out by [15] found that factors influencing the willingness to implement the conservation program are friendships with neighbors, constraints in application and attitudes toward private property. Socioeconomic factors can also influence the willingness to implement a program. These factors are income, number of family members, age, education, farming 
experience and land area. The willingness of farmers will increase if they get support from government, such as the agriculture department and village apparatus. In addition, better coordination between farmer group members is needed so as to facilitate farmers in implementing the program.

\section{CONCLUSION}

The willingness of farmers to continue the LIPM program was still below $50 \%$. Based on the results of the study, it was found that age, LIPM farmers and friendship had a significant and positive impact on the willingness to continue the LIPM program. However, the constraints in implementing the LIPM program, attitudes towards property rights, the contribution of farming income and farming experience had a significant and negative effect on the willingness of the program. Therefore, it is necessary to socialize and assist in the implementation of the program from the government, such as the agriculture department and village apparatus. In addition, better coordination between farmer group members is needed so as to facilitate farmers in implementing the program.

\section{ACKNOWLEDGMENT}

Researchers would like to thank faculty of agriculture Universitas Gadjah Mada and Ministry of Research, Technology and Higher Education for the facilities and financial assistance provided.

\section{REFERENCES}

[1] Food and Agriculture Organization (FAO). 2017. Innovative Rice Farming Systems and Conservation Agriculture. http://www.fao.org/3/a-i5784b.pdf. Retrieved on November $3^{\text {rd } 2017 . ~}$

[2] Irham, Yunita, T., Gatot, M., Gilang, W., Esti., A, and Kukuh, B. 2015. Strengthening and Revitalization of the Integrated Pest Management Indonesia. Yogyakarta: unpublish.

[3] Aisyah, D. 2017. Risiko Produksi dan Pendapatan Usahatani Padi Berbasis Pengendalian Hama Terpadu di Desa Pliken Kecamatan Kembaran Kabupaten Banyumas. Skripsi. Undergraduate Program. UGM.

[4] Kumar, L., Yogi M. K., and Jaba J. 2013. Habitat Manipulation for Biological Control of Insect Pests: A Review. Journal of Agriculture and Forestry Sciences 1 (10) : 27-31

[5] Irham, Pinjung, N.S., Hani P.S., Ridya N., Dinda, D., Bagus D.. 2016. Dampak Pengendalian Hama Terpadu (PHT) Lanskap terhadap Produksi dan Produktivitas Usahatani Padi di Kabupaten Banyumas. Yogyakarta: unpublished.

[6] Putri, A. 2017. Tingkat Adopsi Pengendalian Hama Terpadu Lanskap oleh Petani Padi di Desa Pliken Kecamatan Kembaran Kabupaten Banyumas. Skripsi. Undergraduate Program. UGM.

[7] Stallman, H.R., 2011. Ecosystemservices in Agriculture: Determining Suitability for Provision By Collective Management. Ecological Economics. 71 : 131-139.

[8] Ravnborg, H.M., 2004. Collective Action in Pest Management Brief 11 In: Meinzen-Dick, R., Di Gregorio,M. (Eds.), Collective Action and Property Rights for Sustainable Development. DSE./ZEL Feldafing. Germany.

[9] Stallman H. R. dan H. S. James. 2015. Determinants Affecting Farmers' Willingness to Cooperate to Control Pests. Ecological Economics. 117: 182-192.

[10] Purwanto. 2011. Statistika untuk Penelitian. Pustaka Pelajar. Yogyakarta.

[11] Asra, A dan Rudianstah. 2014. Statistika Terapan Edisi Kedua. IN MEDIA. Bogor.

[12] Perwitasari, H., Irham, S. Hatono, S. Hardyatuti. 2018. Economic Evaluation of Landscape Integrated Pest Management Programs in Banyumas Regency, Central Java, Indonesia. International Journal of Engineering \& Technology 7 (2.29) : $469-475$.
[13] Hariadi, 1996. Faktor Sosial Ekonomi yang Mempengaruhi Petani dalam Penerapan Pengandalian Hama Terpadu (PHT). Journal of Perlindungan Tanaman Indonesia. 2 (1) : 50 - 54.

[14] Wabbi, J B. 2002. Assessing Factors Affecting Adoption of Agricultural Technologies: The Case of Integrated Pest Management (IPM) in Kumi District, Eastern Uganda. Thesis. Virginia Polytechnic Institute and State University.

[15] Amstrong, A and Richard, C. S. 2012. Landowner Willingness to Implement Riparian Buffer in a Transitioning Watershed. Landscape and Urban Planning. 105: 211 - 220 